\title{
Influence of Nitrate on Fermentation Pattern, Molar Growth Yields and Synthesis of Cytochrome $b$ in Propionibacterium pentosaceum
}

\author{
By MARIA L. W. VAN GENT-RUIJTERS, WYTSKE DE VRIES \\ AND A. H. STOUTHAMER \\ Microbiology Department, Biological Laboratory, Free University, \\ de Boelelaan 1087, Amsterdam, The Netherlands
}

(Received 22 August 1974; revised 2 December 1974)

\section{SUMMARY}

Under anaerobic conditions, Propionibacterium pentosaceum reduces nitrate to nitrite until nitrate is exhausted from the medium, when nitrite is converted into $\mathrm{N}_{2}$ or $\mathrm{N}_{2} \mathrm{O}$. In the presence of nitrate, fermentation patterns for lactate, glycerol and pyruvate were different from those obtained during anaerobic growth without an inorganic electron acceptor. In the presence of these substrates, a drastic decrease in propionate formation was observed, some pyruvate accumulated during growth with lactate, and acetate was produced from glycerol. Acetate production from lactate and pyruvate was not influenced by the presence of nitrate. Furthermore, $\mathrm{CO}_{2}$ was produced by citric acid cycle activity. The fermentation pattern during nitrite reduction resembled that of $P$. pentosaceum grown anaerobically without an inorganic electron acceptor. Nitrite has a toxic effect, since bacteria inoculated into a medium with $9 \mathrm{~mm}$-nitrite failed to grow.

The cytochrome spectrum of anaerobically grown $P$. pentosaceum was similar with and without nitrate. In membrane fractions of bacteria grown anaerobically with nitrate, cytochrome $b$ functioned in the transfer of electrons from lactate, glycerol I-phosphate and NADH to nitrate. Molar growth yields were increased in the presence of nitrate, indicating an increased production of ATP. This could be explained by citric acid cycle activity, and by oxidative phosphorylation coupled to nitrate reduction. Assuming that I mol ATP is formed in the electron transfer from lactate or glycerol I-phosphate to nitrate, and that 2 mol ATP are formed in the electron transfer from NADH to nitrate, $Y_{\text {ATP }}$ values (g dry wt bacteria/mol ATP) were obtained of between 5.0 and $12 \cdot 6$. The higher $Y_{\text {ATP }}$ values were similar to those obtained during anaerobic growth without an inorganic electron acceptor. This supports the assumptions about the efficiency of oxidative phosphorylation for electron transport to nitrate. Low $Y_{\text {ATP }}$ values were found when high concentrations of nitrite ( 5 to $50 \mathrm{~mm}$ ) accumulated, and were probably due to the toxic effect of nitrite.

\section{INTRODUCTION}

Nitrate respiration is a widespread property of bacteria (Payne, 1973; Pichinoty, 1973) and even in anaerobic bacteria such as Veillonella alcalescens (Inderlied \& Delwiche, I973; de Vries, van Wijck-Kapteyn \& Oosterhuis, 1974), Selenomonas ruminantium (de Vries et al. 1974) and Clostridium perfringens (Ishimoto, Umeyama \& Chiba, 1974), nitrate may serve as terminal electron acceptor in anaerobic respiration. In most cases, cytochromes are involved in nitrate reduction (Payne, 1973; Pichinoty, 1973). Cytochromes function in electron transport to fumarate in a number of anaerobic bacteria which form propionate (or succinate) via the succinate pathway. Such bacteria include Bacteroides spp. (White, 
Bryant \& Caldwell, 1962; Rizza et al. 1968), Vibrio succinogenes (Jacobs \& Wolin, 1963), propionic acid bacteria (Chaix \& Fromageot, 1942; de Vries, van Wijck-Kapteyn \& Stouthamer, 1972; Sone, 1972), Desulfovibrio gigas (Hatchikian \& Le Gall, 1972), and V. alcalescens, S. ruminantium and Anaerovibrio lipolytica (de Vries et al. 1974). Cytochromes are involved in anaerobic electron transport to nitrate in $V$. alacalescens and $S$. ruminantium (de Vries et al. 1974), while reduced ferredoxin is the electron donor for nitrate reduction in C. perfringens (Chiba \& Ishimoto, 1973).

Denitrification is less widespread among bacteria (Payne, I973; Pichinoty, 1973). The only anaerobe in which it has been observed is Propionibacterium pentosaceum (Bergey's Manual of Determinative Bacteriology, 1957). de Vries et al. (1972) investigated the influence of oxygen on growth, fermentation pattern and cytochrome synthesis in propionic acid bacteria. They found that fermentation does not occur in the presence of air, when these bacteria presumably obtain energy by oxidative phosphorylation with oxygen as electron acceptor although cytochrome synthesis is repressed by oxygen. In the present investigation the influence of denitrification on fermentation pattern and molar growth yields in $P$. pentosaceum was studied in order to determine whether energy is generated by electron transport to nitrate and nitrite. The influence of nitrate on cytochrome synthesis and the possible role of cytochrome $b$ in nitrate reduction were also investigated.

\section{METHODS}

Organism and growth conditions. Propionibacterium pentosaceum (de Vries et al. 1972) was used throughout.

Absorption spectra and reduction kinetics of cytochrome $b$ were measured on bacteria grown in a complex medium containing (per 1 deionized water): tryptone, $5 \mathrm{~g}$; yeast extract, IO g; $\mathrm{KH}_{2} \mathrm{PO}_{4}, 250 \mathrm{mg} ; \mathrm{MnSO}_{4}, 5 \mathrm{mg}$; $\mathrm{pH} 6.5$. Sodium DL-lactate or glycerol were added as required. $\mathrm{KNO}_{3}$ was added to a concentration of 0.5 or $\mathrm{I} \%(\mathrm{w} / \mathrm{v})$.

Growth experiments were performed in a semi-synthetic medium containing (per 1 deionized water): casein hydrolysate, $5 \mathrm{~g} ; \mathrm{K}_{2} \mathrm{HPO}_{4}, 3 \cdot 75 \mathrm{~g} ; \mathrm{KH}_{2} \mathrm{PO}_{4}, 3 \cdot 75 \mathrm{~g}$; tryptophan, $100 \mathrm{mg}$; L-cysteine, $5 \mathrm{mg}$; sodium thioglycollate, $20 \mathrm{mg} ; \mathrm{MgSO}_{4} \cdot 7 \mathrm{H}_{2} \mathrm{O}, 325 \mathrm{mg} ; \mathrm{CaCO}_{3}$, IO mg; $\mathrm{FeSO}_{4} .7 \mathrm{H}_{2} \mathrm{O}, 22.6 \mathrm{mg} ; \mathrm{ZnSO}_{4} .7 \mathrm{H}_{2} \mathrm{O}, 7.2 \mathrm{mg} ; \mathrm{MnSO}_{4} .4 \mathrm{H}_{2} \mathrm{O}, 5.6 \mathrm{mg} ; \mathrm{CuSO}_{4} .5 \mathrm{H}_{2} \mathrm{O}$, $\mathrm{I} \cdot 2 \mathrm{mg} ; \mathrm{CoCl}_{2} \cdot 6 \mathrm{H}_{2} \mathrm{O}, \mathrm{I} \cdot 2 \mathrm{mg} ; \mathrm{H}_{3} \mathrm{BO}_{3}, 0.3 \mathrm{mg}$; adenine, guanine, uracil and xanthine, each $0.5 \mathrm{mg}$; biotin, $0.14 \mathrm{mg}$; thiamin, $0.2 \mathrm{mg}$; riboflavin, $0.2 \mathrm{mg}$; pyridoxin, $0.4 \mathrm{mg}$; calcium pantothenate, $0.2 \mathrm{mg}$; nicotinic acid, $0.2 \mathrm{mg}$; p-aminobenzoic acid, $0.02 \mathrm{mg}$; pH 6.5, together with growth-limiting concentrations of sodium DL-lactate (up to $25 \mathrm{~mm}$ ), glycerol (up to $5 \mathrm{~mm}$ ) or sodium pyruvate (up to $20 \mathrm{~mm}$ ). Pyruvate was sterilized by filtration. $\mathrm{KNO}_{3}$ was added as required.

Small volumes of cultures were grown at $30{ }^{\circ} \mathrm{C}$ under $95 \% \mathrm{~N}_{2}+5 \% \mathrm{CO}_{2}$ in stainless steel anaerobic jars manufactured in our laboratory. Larger volumes were grown in a Chemap Vibro-glass fermenter (Chamap AG, Männedorf $\mathrm{ZH}$, Switzerland) at $30^{\circ} \mathrm{C}$ under a stream of $95 \% \mathrm{~N}_{2}+5 \% \mathrm{CO}_{2}$. In cultures in the complex medium containing glycerol the pH was controlled at 6.5 (de Vries, van Wijck-Kapteyn \& Stouthamer, I973). Under other growth conditions $\mathrm{pH}$ control was unnecessary since variations were less than $0 \cdot \mathrm{I}$ unit. Growth was estimated turbidimetrically at $660 \mathrm{~nm}$ in I cm cuvettes. Bacterial suspensions and membrane fractions were prepared from cultures harvested at an extinction between 0.45 and $\mathrm{I} \cdot \mathrm{O}$. Dry weights were measured by membrane filtration as described by de Vries \& Stouthamer (1968).

Determination of lactate, pyruvate, fermentation products and nitrite in supernatant fluids. Total lactate, succinate and propionate were measured by gas-liquid chromatography using 
a Hewlett Packard gas chromatograph model 5750G (Hewlett Packard GmbH, Böblingen, Germany) fitted with a flame ionization detector and with $\mathrm{N}_{2}(35 \mathrm{ml} / \mathrm{min})$ as the carrier gas. For measuring lactate and succinate a $6 \mathrm{ft} \times \frac{1}{8}$ in stainless-steel column was used packed with Resoflex LAC-I-R-296 (Burrell Corp., Pittsburg, Pennsylvania, U.S.A.) at a temperature of $130{ }^{\circ} \mathrm{C}$. Lactate and succinate were measured as the methyl derivatives, prepared as described in the Anaerobe Laboratory Manual (1972). Propionate was measured with the column described above (temperature $135^{\circ} \mathrm{C}$ ) or with a $6 \mathrm{ft} \times \frac{1}{11}$ in glass column (WEBOCO, Zevenaar, Holland) packed with Chromosorb ror (80/100 mesh; Becker Delft NV, The Netherlands) using a glass injection port and a temperature of $150^{\circ} \mathrm{C}$. Propionate was measured by direct injection of culture supernatants into the columns. With the glass column, propionate was completely separated from acetate. The lactate, succinate and propionate contents were calculated from the peak heights and reference to standards. Acetate was determined by the enzymic method of Rose et al. (1954), which is based on the colorimetric determination of acetyl phosphate according to Lipmann \& Tuttle (1945). L-Lactate was measured enzymically by the method of Hohorst (I970) and D-lactate by the enzymic method of Gahwehn \& Bergmeyer (1970). Pyruvate was measured enzymically with lactate dehydrogenase in a reaction mixture containing: tris buffer $\mathrm{pH} 7.4,40 \mathrm{mM}$; $\mathrm{MgCl}_{2}, 4 \mathrm{~mm}$; NADH, $0.36 \mathrm{~mm}$. Nitrite was measured as described by van 't Riet, Stouthamer \& Planta (1968).

Measurement of carbon dioxide evolution and gas production from nitrate. These were measured by Warburg manometry.

$\mathrm{CO}_{2}$ evolution was measured in $75 \mathrm{ml}$ capacity Warburg flasks with cultures growing in semi-synthetic medium under $\mathrm{N}_{2} / \mathrm{CO}_{2}$ at $30{ }^{\circ} \mathrm{C}$. Conditions were chosen so that no gas was produced from nitrate (see Results). The $\mathrm{pH}$ of the buffered medium remained constant throughout the experiment.

For measuring gas evolution from nitrate, the $\mathrm{CO}_{2}$ evolved was absorbed by $0.2 \mathrm{ml}$ of a $10 \%(\mathrm{w} / \mathrm{v}) \mathrm{KOH}$ solution in the centre well of a $25 \mathrm{ml}$ capacity Warburg flask at $30{ }^{\circ} \mathrm{C}$. It was necessary to use pure $\mathrm{N}_{2}$ instead of the $\mathrm{N}_{2} / \mathrm{CO}_{2}$ gas mixture for anaerobiosis in these experiments. Since growth under $\mathrm{N}_{2}$ was very slow in the semi-synthetic medium, a complex medium was used.

During both types of Warburg experiment, samples were taken for the measurement of the extinction and the determination of fermentation products and nitrite.

Preparation of bacterial suspensions and membrane fractions. For the preparation of cell suspensions, bacteria were harvested at $4{ }^{\circ} \mathrm{C}$, washed twice with a chilled $0.067 \mathrm{M}$ phosphate buffer pH 6.8 and resuspended in this buffer to about 15 to $45 \mathrm{mg}$ dry wt bacteria/ ml. Membrane fractions were prepared as described by de Vries et al. (1972, 1973). Protein was measured by the method of Lowry et al. (I95I), using bovine serum albumin as standard.

Measurement of difference spectra and reduction kinetics of cytochrome b. Reduced minus oxidized difference spectra of bacterial suspensions were recorded with an Aminco Chance spectrophotometer (American Instruments Co., Inc.). Cytochrome $b$ was estimated from dithionite-reduced minus oxygen-oxidized difference spectra between 400 and $700 \mathrm{~nm}$ using $\epsilon=175001 / \mathrm{mol} / \mathrm{cm}$ (Deeb \& Hager, 1964).

The reduction of cytochrome $b$ by membrane suspensions was followed with an Aminco Chance spectrophotometer set in the dual-wavelength position using 562 and $578 \mathrm{~nm}$ as the sample and reference wavelengths, respectively. To $3 \mathrm{ml}$ (or $1.5 \mathrm{ml}$ ) of the membrane suspension ( 2 to $5 \mathrm{mg}$ protein $/ \mathrm{ml}$ ), oxidized with air, was added $50 \mu \mathrm{l}$ (or $25 \mu \mathrm{l}$ ) of 0.2 M-NADH, $0.5 \mathrm{M}$ L-lactate, glycerol I-phosphate or pyruvate, or potassium nitrate. 


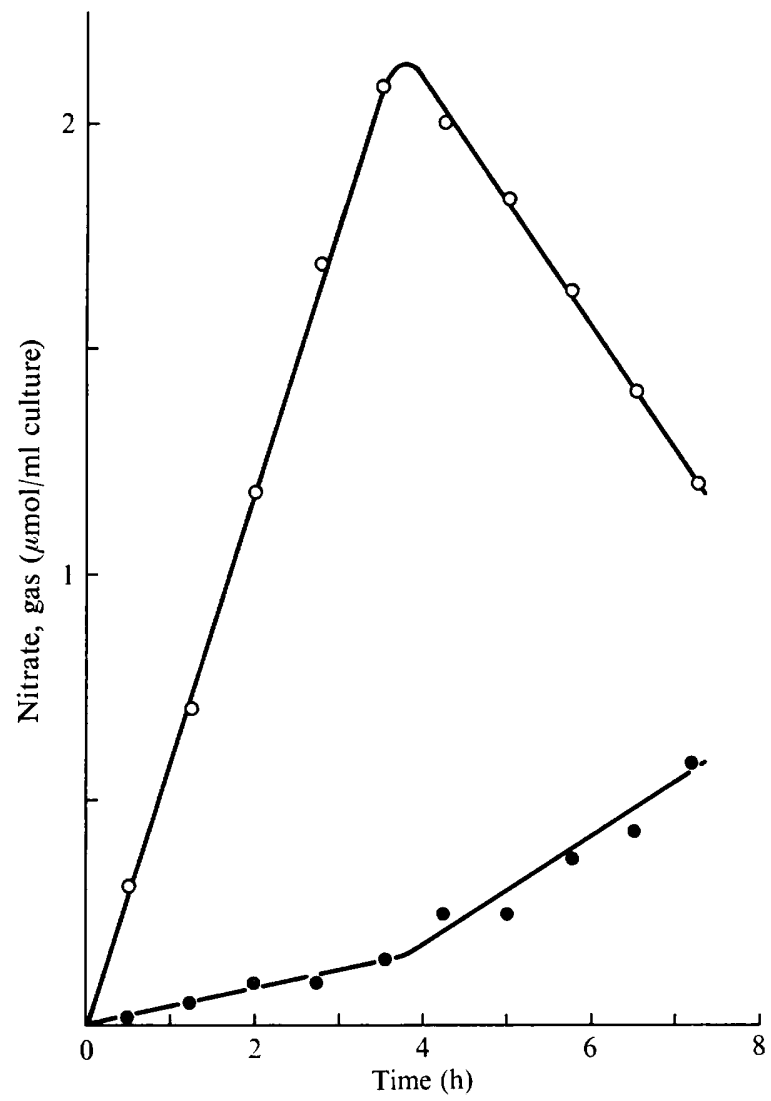

Fig. I. Nitrite and gas production in cultures of $P$. pentosaceum growing anaerobically in the presence of $25 \mathrm{~mm}$-lactate and $2.5 \mathrm{mM}-\mathrm{KNO}_{3}$. Each Warburg flask contained $3 \mathrm{ml}$ of culture and $\mathrm{KOH}$ in the centre well. At regular intervals the culture from one flask was harvested for the determination of the nitrite content in the supernatant fluid. Gas evolution was calculated from the mean values of four flasks on the assumption that $\mathrm{N}_{2}$ was formed; values for $\mathrm{NO}$ would be about $2 \%$ higher and for $\mathrm{N}_{2} \mathrm{O} 9 \%$ higher.

Chemicals. Tryptone and casein hydrolysate were obtained from Oxoid, and yeast extract from Difco. Sodium DL-lactate solution containing $63 \%$ L-lactate and $7 \%$ Dlactate was obtained from BDH. Glycerol, sodium pyruvate, potassium nitrate and sodium nitrite were obtained from Merck. NADH, NAD and all the enzymes used were obtained from Boehringer, Mannheim, Germany. Sodium DL-glycerol I-phosphate and sodium L-lactate were obtained from Serva, Entwicklungslabor, Heidelberg, Germany. 2-n-Heptyl4-hydroxyquinoline- $N$-oxide (HOQNO) was obtained from Sigma.

\section{RESULTS}

\section{Strain and medium}

One out of three strains of $P$. pentosaceum tested appeared able to reduce nitrate to nitrite and, when nitrate was exhausted, to reduce nitrite further.

In the complex medium, without an additional energy source and without nitrate, bacteria grew anaerobically to an extinction of 0.39 and propionate $(6.3 \mathrm{~mm})$ accumulated. In the 


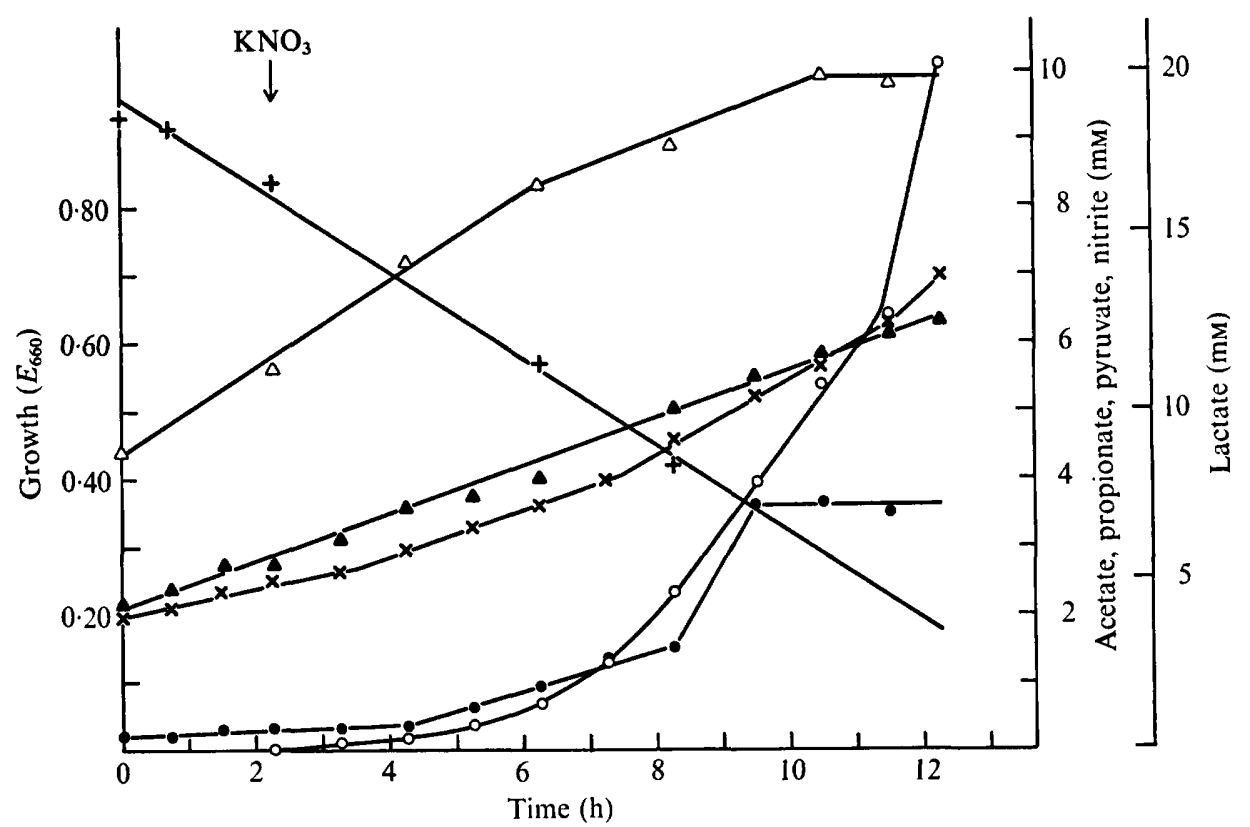

Fig. 2. Influence of nitrate reduction on lactate metabolism of $P$. pentosaceum. To a culture growing anaerobically with $25 \mathrm{~mm}$-lactate, $\mathrm{KNO}_{3}$ was added to a final concentration of $10 \mathrm{~mm}$ when the culture density $\left(E_{660}\right)$ reached $0.25 . \times$, Growth; + , lactate; $\boldsymbol{\Delta}$, acetate; $\triangle$, propionate; $\boldsymbol{O}$, pyruvate; $\bigcirc$, nitrite.

presence of nitrate $\left(0.5 \% \mathrm{KNO}_{3}\right)$ an extinction of $\mathrm{I} \cdot \mathrm{I}$ was reached, a large amount of nitrite accumulated $(24.6 \mathrm{~mm})$, and acetate $(4.9 \mathrm{~mm})$ and propionate $(0.9 \mathrm{~mm})$ were formed. The complex medium, which was used in an earlier study (de Vries et al. 1972), contained fermentable and nitrate-oxidizable organic compounds such as lactate (approx. $6 \mathrm{~mm}$ lactate was detected); these disadvantages made it unsuitable for the present study of nitrate reduction in $P$. pentosaceum. In the semi-synthetic medium without added energy source, very low extinctions of 0.05 and 0.12 were reached in the absence and presence of nitrate $\left(0.5 \% \mathrm{KNO}_{3}\right)$ respectively, and furthermore little nitrite $(2.5 \mathrm{~mm})$ was produced in the presence of nitrate. Evidently, the semi-synthetic medium contained only a few fermentable and nitrate-oxidizable organic compounds, and it was used for growth experiments. Since growth on this medium with pure $\mathrm{N}_{2}$ for anaerobiosis was very slow, $95 \% \mathrm{~N}_{2}+5 \% \mathrm{CO}_{2}$ was used. In this medium, with lactate as energy source, the specific growth rate was about $0 \cdot \mathrm{I} \mathrm{h}^{-1}$ and was not influenced by the presence or absence of nitrate.

\section{Reduction of nitrate to nitrite and further reduction of nitrite}

A typical experiment in which a small amount of nitrate was used is shown in Fig. I. After about $4 \mathrm{~h}$, nitrite production was maximal with $85 \%$ of the added nitrate recovered as nitrite. Afterwards, nitrite disappeared and the rate of gas production increased. Since I mol gas was formed from 2 mol nitrite, the gas formed was either $\mathrm{N}_{2}$ or $\mathrm{N}_{2} \mathrm{O}$.

\section{Influence of nitrate on fermentation pattern}

Nitrate was added to cultures containing lactate and fermentation products and nitrite, were determined at intervals. The rate of nitrite production was slow initially, but gradually 
Nitrate reduction in P. pentosaceum

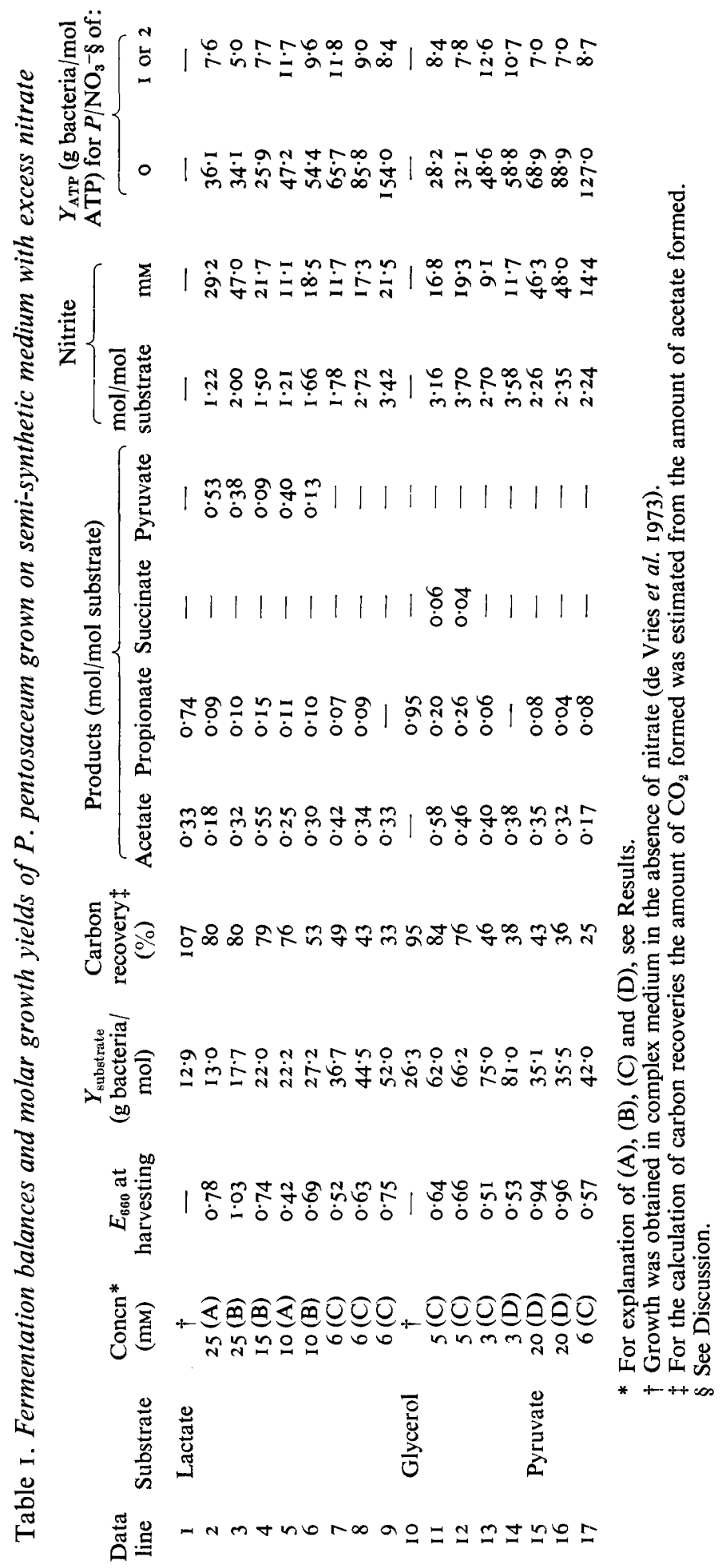




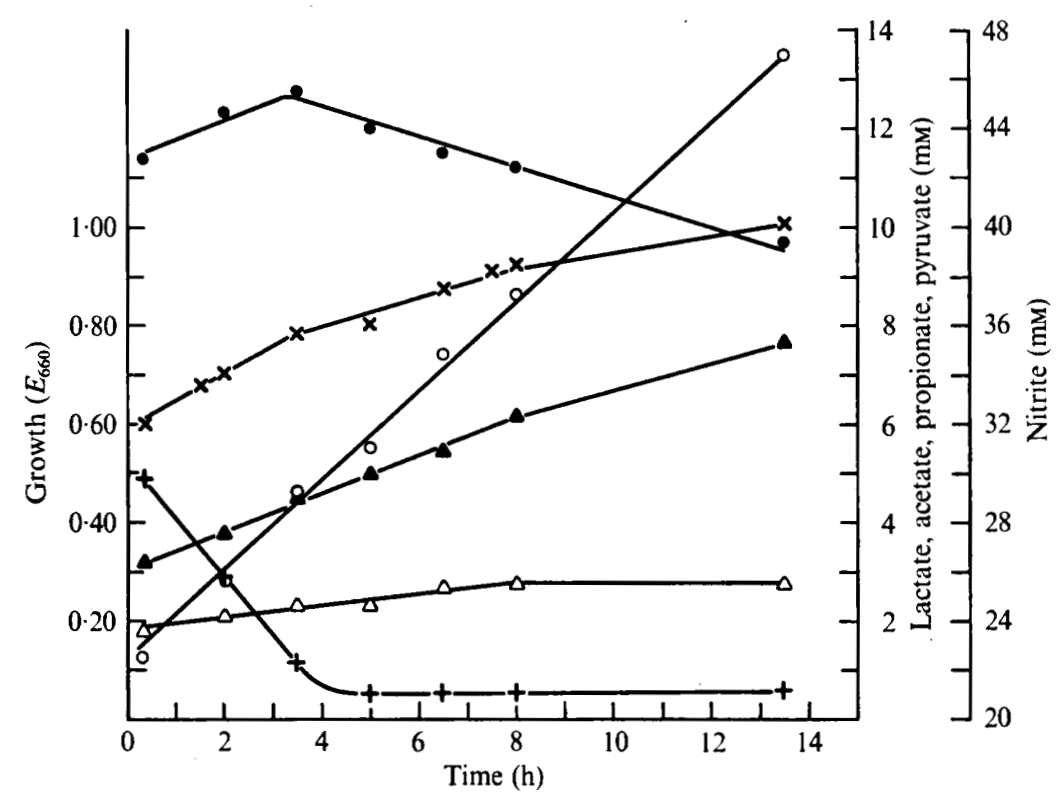

Fig. 3. Accumulation and degradation of pyruvate in a culture of $P$. pentosaceum growing with 25 mM-lactate and $\mathrm{I} \% \mathrm{KNO}_{3}$. For symbols, see Fig. 2.

increased (Fig. 2). Acetate production from lactate was not influenced by the addition of nitrate. Propionate formation diminished and finally ceased while some pyruvate accumulated. No succinate production was detected. At the end of the experiment (Io $\mathrm{h}$ after the addition of $10 \mu \mathrm{mol}$ nitrate $/ \mathrm{ml}$ ), $14.7 \mathrm{~mm}$-lactate were converted into $3.4 \mathrm{~mm}$-acetate, 4.2 mM-propionate and $3.3 \mathrm{~mm}$-pyruvate, accompanied by the formation of $10 \mathrm{~mm}$-nitrite. Thus, when high concentrations of nitrate were used, all the nitrate added was converted into nitrite. Assuming that the production of one mole of acetate was accompanied by the formation of one mole of $\mathrm{CO}_{2}$, the carbon recovery was $74 \%$.

Since the results showed that fermentation continued for several hours after the addition of nitrate, in subsequent experiments medium containing nitrate was inoculated with cultures grown in the presence of nitrate. To prevent nitrite reduction, an excess of nitrate (final concn 0.5 or $\mathrm{I} \cdot 0 \%, \mathrm{w} / \mathrm{v}, \mathrm{KNO}_{3}$ ) was added.

\section{Fermentation balances and molar growth yields during nitrate reduction}

Fermentation balances and molar growth yields for growth of $P$. pentosaceum on lactate, glycerol or pyruvate were determined in the presence of an excess of nitrate (Table I). For comparison, this Table also contains fermentation balances and molar growth yields for growth with lactate and glycerol in the absence of nitrate (de Vries et al. 1973). In cultures growing with lactate (Fig. 3) pyruvate accumulated initially but was degraded when lactate was almost exhausted from the medium, and growth continued at a slower rate. Even when pyruvate had been completely consumed growth continued slowly. In media containing lactate, fermentation balances were determined (see Table I) at the moment at which lactate was exhausted (A), during growth on the accumulated pyruvate (B) and when pyruvate was exhausted (C). In media containing glycerol and pyruvate, fermentation balances were determined when growth was very slow (C) or had ceased (D). No pyruvate could be 
Table 2. $\mathrm{CO}_{2}$ production and acetate formation during growth of $P$. pentosaceum

\begin{tabular}{cccccc}
$\begin{array}{c}\text { Growth } \\
\left(E_{660}\right)\end{array}$ & $\begin{array}{c}\text { Acetate } \\
(\mu \mathrm{mol} / \mathrm{ml} \\
\text { culture })\end{array}$ & $\begin{array}{c}\mathrm{CO}_{2} \\
(\mu \mathrm{mol} / \mathrm{ml} \\
\text { culture })\end{array}$ & $\begin{array}{c}\text { Ratio } \\
\mathrm{CO}_{2} / \text { acetate } \\
(\mathrm{mol} / \mathrm{mol})\end{array}$ & $\overbrace{(\mathrm{A})}^{\begin{array}{c}\text { Carbon recovery } \\
(\%)\end{array}}$ \\
$0.085-0.68$ & $4 \cdot 7$ & $12 \cdot 7$ & $2 \cdot 7$ & 69 & (B) \\
$0.74-0.80$ & $1 \cdot 4$ & 4.6 & 3.3 & 55 & 80 \\
\hline
\end{tabular}

Each Warburg flask contained $20 \mathrm{ml}$ of culture growing with $25 \mathrm{~mm}+$ lactate and I \% (w/v) $\mathrm{KNO}_{3}$. In the first experiment, lactate was used as energy source. In the second experiment, lactate was exhausted from the medium and growth continued on the pyruvate accumulated. Carbon recoveries were calculated (A) without and (B) with the $\mathrm{CO}_{2}$ produced in excess of acetate.

detected at the moment of harvesting. In all cases, corrections were made for growth on the medium with added nitrate but without added substrate.

From Table I, it appears that nitrate increased the molar growth yields for both lactate and glycerol. Furthermore, it is evident that the amount of propionate formed per mole of substrate was much less during growth with nitrate. In general, the carbon recovery with lactate and glycerol was about $80 \%$ when bacteria were harvested in the early stages of growth. However, when bacteria were harvested later, molar growth yields were higher but the carbon recoveries became less satisfactory. For the calculation of carbon recoveries, it was always assumed that equal quantities of acetate and $\mathrm{CO}_{2}$ were produced. Furthermore, considering any one substrate concentration, it is apparent that nitrite production $(\mathrm{mol} / \mathrm{mol}$ substrate) was higher with harvesting later during growth.

One reason for the low carbon recoveries might be the excretion of one or more metabolic intermediates. However, in extensive experiments we could not detect any such metabolic product. Another reason might be $\mathrm{CO}_{2}$ production by citric acid cycle activity (Delwiche \& Carson, I953; de Vries, unpublished results). In Warburg experiments it was shown that at the end of growth $\mathrm{CO}_{2}$ production continued at a constant rate whereas acetate production diminished. In growing bacteria $\mathrm{CO}_{2}$ evolution exceeded acetate production (Table 2), which indicates that $\mathrm{CO}_{2}$ is indeed produced by citric acid cycle activity. Improved results are achieved by calculating carbon recoveries including the $\mathrm{CO}_{2}$ produced in excess of acetate. Hence, $\mathrm{CO}_{2}$ evolution by citric acid cycle activity accounts (at least in part) for the low carbon recoveries in our experiments. The conclusion that $\mathrm{CO}_{2}$ is produced by citric acid cycle activity is further strengthened by the observation that in general a small decrease in the sum of the amounts of acetate and pyruvate occurred during longer incubation. Furthermore, the nitrite production per mole of substrate converted was higher than the theoretical amount required to convert lactate (2), glycerol (3) and pyruvate (I) into acetate. Therefore, citric acid cycle activity might explain the high molar growth yields and nitrite production when harvesting at the end of growth.

\section{Influence of nitrite reduction on fermentation pattern}

With bacteria grown in the presence of limited amounts of nitrate ( 7 to $12 \mathrm{~mm}$ ), growth continued after nitrate had been completely converted into nitrite, and nitrite was reduced slowly. Pyruvate, accumulated during nitrate reduction in a medium containing lactate, remained constant and the rate of acetate production did not change. The most important observation during nitrite reduction was that propionate production, which had stopped during nitrate reduction, started again. Thus during nitrite reduction the fermentation 
Table 3. Influence of nitrate on cytochrome b synthesis of $P$. pentosaceum

$\begin{array}{lcc}\text { Growth conditions } & \text { Substrate } & \begin{array}{c}\text { Cytochrome } b \text { content } \\ (\mu \mathrm{mol} / \mathrm{g} \text { dry wt bacteria* }\end{array} \\ \text { Anaerobic } \dagger & \text { Lactate } & 0.25 \\ \text { Aerobic } \dagger & \text { Lactate } & 0.05 \\ \text { Anaerobic }+0.5 \%(\mathrm{w} / \mathrm{v}) \mathrm{KNO}_{3} & \text { Lactate } & 0.11-0.19 \\ \text { Anaerobic }+\mathrm{I} \%(\mathrm{w} / \mathrm{v}) \mathrm{KNO}_{3} & \text { Glycerol } & 0.10-0.18 \\ * \text { Dry weights of nitrate-grown cells were calculated from the relationship: } \\ \quad \text { dry weight }(\mathrm{g} / \mathrm{ml})=0.43 \times 10^{-3} E_{660} .\end{array}$

pattern resembled that of $P$. pentosaceum grown anaerobically without nitrate (de Vries et al. 1973).

\section{Influence of nitrate on cytochrome synthesis}

After anaerobic growth with excess nitrate, reduced minus oxidized difference spectra of $P$. pentosaceum were essentially the same as those of anaerobically grown $P$. freudenreichii (de Vries et al. 1972), with cytochrome $b(\alpha$-peak at $562 \mathrm{~nm}, \beta$-peak at $532 \mathrm{~nm}$, Soret peak at $429 \mathrm{~nm}$ ), cytochrome $a$ or $a_{1}$ ( $\alpha$-peak at $606 \mathrm{~nm}$ ), flavoproteins (trough at $460 \mathrm{~nm}$ ) and sometimes cytochrome $a_{2}$ ( $\alpha$-peak at $630 \mathrm{~nm}$ ) present.

The contents of cytochrome $b$ were measured in bacteria grown anaerobically with excess nitrate, plus lactate or glycerol (Table 3 ). The cytochrome $b$ content of $P$. pentosaceum after anaerobic growth with lactate was less when nitrate was present than in its absence. However, no drastic decrease of cytochrome $b$ content in nitrate-grown bacteria occurred such as was found after aerobic growth by de Vries et al. (1972).

\section{Reduction kinetics of cytochrome $b$ in membrane fractions}

Dual-wavelength experiments showed that membrane suspensions from $P$. pentosaceum grown with lactate and nitrate reduced cytochrome $b$ in the presence of L-lactate and NADH, but not in the presence of pyruvate. After addition of NADH to membrane suspensions oxidized with air (Fig. 4 , I), the 'aerobic steady state' (40\% reduction of cytochrome $b$ as compared with reduction by dithionite) was attained within $40 \mathrm{~s}$. When oxygen was exhausted from the suspension an 'anaerobic steady state' (78\% reduction of cytochrome $b$ ) was reached at about I I min after addition of NADH. Nitrate oxidized cytochrome $b$ to a steady state of $44 \%$ reduction. A second steady state ( $22 \%$ reduction) was reached 9 min after addition of nitrate, due to exhaustion of NADH from the suspension. In the presence of HOQNO, an inhibitor of cytochrome $b$ function (Cox et al. 1970), both the aerobic steady state and the steady state with nitrate were prolonged (Fig. 4, II). L-Lactate reduced cytochrome $b$ more slowly than NADH (Fig. 4, III); consequently, the aerobic steady state (3I \% reduction of cytochrome $b$ ) lasted longer and more time was needed before the anaerobic steady state $(7 \mathrm{I} \%$ reduction of cytochrome $b$ ) was reached. Nitrate oxidized cytochrome $b$ to the same level as during the aerobic steady state.

Membrane suspensions from $P$. pentosaceum, grown with glycerol and nitrate, reduced cytochrome $b$ in the presence of glycerol I-phosphate (Fig. 4, IV) and NADH. Glycerol I-phosphate reduced cytochrome $b$ to $72 \%$, and nitrate oxidized cytochrome $b$ to a steady state value of $48 \%$ reduction. 


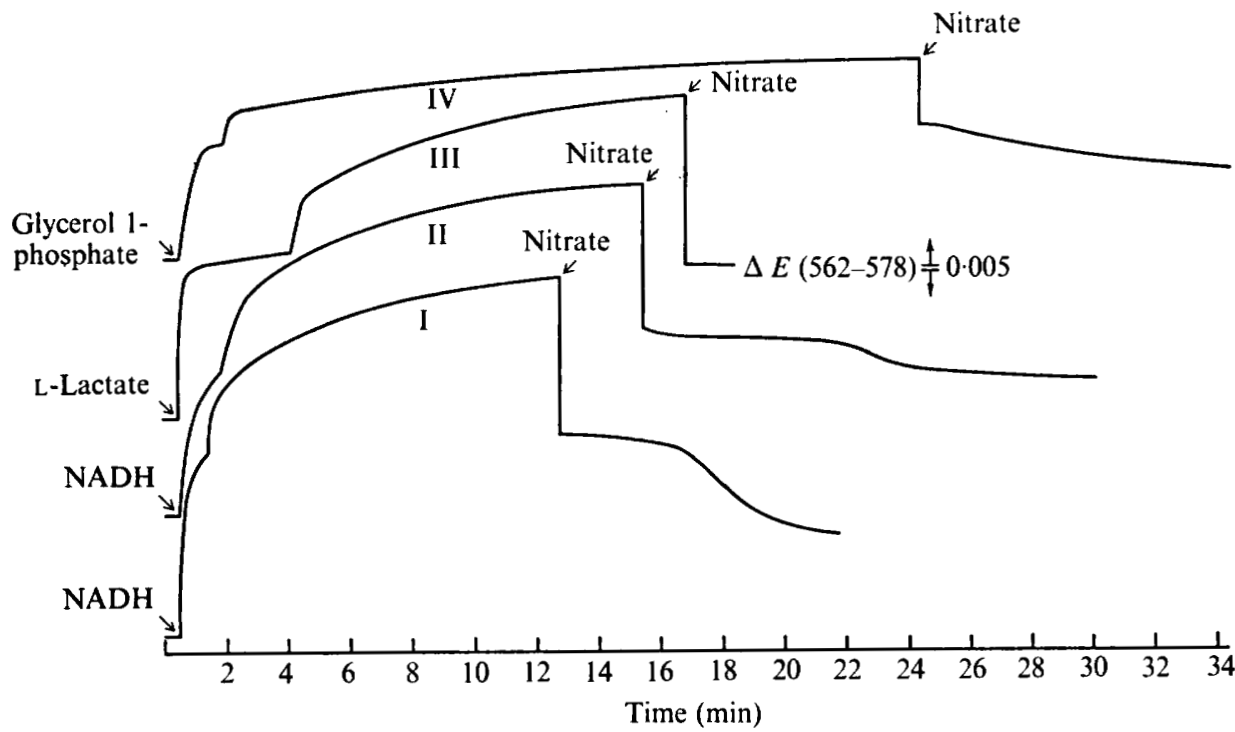

Fig. 4. Reduction of cytochrome $b$ with L-lactate (III) and NADH in the absence (I) and presence (II) of $2.5 \mu \mathrm{M}-\mathrm{HOQNO}$ by a crude membrane fraction $(2.1 \mathrm{mg}$ protein/ml) from $P$. pentosaceum, grown with $0.15 \%(\mathrm{w} / \mathrm{v})$ lactate and $0.5 \%(\mathrm{w} / \mathrm{v}) \mathrm{KNO}_{3}$. Reduction of cytochrome $b$ with glycerol I-phosphate (IV) by a crude membrane fraction $(3.4 \mathrm{mg}$ protein $/ \mathrm{ml})$ from $P$. pentosaceum, grown with $0.17 \%(\mathrm{w} / \mathrm{v})$ glycerol and $\mathrm{I} \%(\mathrm{w} / \mathrm{v}) \mathrm{KNO}_{3}$. Re-oxidation of cytochrome $b$ by nitrate.

\section{DISCUSSION}

Denitrification has been demonstrated in P. pentosaceum. Nitrate interferes, just as does oxygen (de Vries et al. 1972), with the normal propionic acid fermentation, and acetate is the main end product during nitrate reduction. In addition, a large amount of $\mathrm{CO}_{2}$ is formed by citric acid cycle activity. During the reduction of nitrite, however, the propionic acid fermentation occurs normally. Oxygen represses the synthesis of cytochrome $b$ in propionibacteria (de Vries et al. 1972) and this is the principal reason for the anaerobic character of these bacteria. This effect is not shown by nitrate, although some reduction in the cytochrome $b$ content does occur.

The influence of nitrate on molar growth yields has been studied in a number of facultative bacteria. In Aerobacter aerogenes (Hadjipetrou \& Stouthamer, I965), Proteus mirabilis (Stouthamer \& Bettenhaussen, 1972) and Citrobacter freundii (Kaprálek, 1972) molar growth yields were increased in the presence of nitrate. From these results it was concluded that nitrate reduction is accompanied by oxidative phosphorylation. A similar conclusion can be drawn from this study with $P$. pentosaceum.

Fermentation patterns have been proposed from previous yield studies with propionibacteria growing anaerobically with various substrates in the absence of nitrate (de Vries et al. I973). In these schemes it was postulated that I mol ATP is formed in the transfer of an electron pair from lactate and glycerol $\mathrm{I}$-phosphate to fumarate $(P / 2 e=\mathrm{I}$, where $P$ is ATP, and $2 e$ an electron pair) and that $2 \mathrm{~mol} \mathrm{ATP} \mathrm{are} \mathrm{formed} \mathrm{in} \mathrm{the} \mathrm{electron}$ transport from NADH to fumarate $(P / 2 e=2)$. This was based on the finding that in propionibacteria lactate and glycerolphosphate are oxidized by flavoproteins. Consequently in the electron transfer to cytochrome $b$, which is the ultimate electron donor for fumarate reduction, more phosphorylation sites may be present between NADH and 
cytochrome $b$ than between reduced flavins and cytochrome $b$. These assumptions are supported by the observation that the $Y_{\mathrm{ATP}}$ values (g dry wt bacteria/mol ATP) for each organism were similar for growth with different substrates on the same medium. For $P$. pentosaceum grown on semi-synthetic medium, $Y_{\mathrm{ATP}}$ values of II.5 and I2.I were calculated. Furthermore, unreasonably high $Y_{\text {ATP }}$ values were obtained if no allowance was made for oxidative phosphorylation during anaerobic electron transport.

From our experiments $Y_{\text {ATP }}$ values were calculated by dividing molar growth yields by ATP yields. ATP yields were calculated from the schemes for lactate and glycerol fermentation and ATP formation postulated by de Vries et al. (1973). During nitrate reduction acetate was produced in much larger amounts than propionate (Table I); therefore sufficient NADH is produced during acetate formation to account for the reduction of fumarate and oxaloacetate in the formation of propionate. Hence 2 mol ATP will be produced during electron transport from NADH to fumarate, and the production of I mol propionate or succinate will be accompanied by the production of 2 mol ATP. When ATP production by substrate level phosphorylation and during electron transport to fumarate is taken into account, and oxidative phosphorylation during the electron transport to nitrate is ignored, unreasonably high $Y_{\text {ATP }}$ values are found (between $25^{\circ}$ a and 154.0). Forrest \& Walker (I97I) and Stouthamer (1973) calculated that theoretical maximum $Y_{\text {ATP }}$ values lie between $26 \cdot 7$ and $32 \cdot \mathrm{I}$. For some organisms, maximum $Y_{\mathrm{ATP}}$ values are found which approach the theoretical values very closely (de Vries et al. 1970; Stouthamer \& Bettenhaussen, 1973). We therefore conclude that nitrate reduction in $P$. pentosaceum is associated with oxidative phosphorylation.

We also propose that I mol ATP is formed in the transfer of an electron pair from lactate and glycerol I-phosphate to nitrate $\left(P / \mathrm{NO}_{3}{ }^{-}=\mathrm{I}\right)$ and 2 mol ATP in the transfer of an electron pair from NADH to nitrate $\left(P / \mathrm{NO}_{3}{ }^{-}=2\right)$. In our experiments nitrate will be reduced by lactate and glycerol I-phosphate with a $P / \mathrm{NO}_{3}{ }^{-}$value of $\mathrm{I}$, and by the NADH not used in the reduction of fumarate and oxaloacetate with a $P / \mathrm{NO}_{3}-$ of 2 . With pyruvate as the substrate, all electron transport to nitrate proceeds via $\mathrm{NADH}\left(P / \mathrm{NO}_{3}{ }^{-}=2\right)$.

In our calculations, the extent of oxidative phosphorylation in the electron transport to nitrate was deduced from the amount of nitrite formed. For instance, during growth with lactate (Table I, data line 2) the nitrite production per mole of lactate is $\mathrm{I} \cdot 22 \mathrm{~mol}$, I mol of which will be produced during the conversion of lactate into pyruvate and the remaining part $(0.22 \mathrm{~mol})$ during the further conversion of pyruvate. Thus the ATP yield from lactate may be calculated as follows: 0.18 (acetate formation) $+0.09 \times 2$ (propionate formation) $+\mathrm{I} \cdot 0 \times \mathrm{I}$ $\left(P / \mathrm{NO}_{3}{ }^{-}=\mathrm{I}\right)+0.22 \times 2\left(P / \mathrm{NO}_{3}^{-}=2\right)$. The ATP yield from glycerol (Table $\mathrm{I}$, data line I I ) was calculated as follows: $I \cdot 0$ (Embden-Meyerhof pathway) +0.58 (acetate formation) + $0.20 \times 2$ (propionate formation) $+0.06 \times 2$ (succinate formation) $+\mathrm{I} \cdot 0 \times \mathrm{I}$ (glycerolphosphate oxidation with a $\left.P / \mathrm{NO}_{3}{ }^{-}=\mathrm{I}\right)+2\left(P / \mathrm{NO}_{3}{ }^{-}\right) \times 2 \cdot 16$ (amount of nitrite formed per mole of glycerol minus one, produced during the oxidation of glycerolphosphate). The ATP yield from pyruvate (Table I, data line I 5) was calculated as follows: 0.35 (acetate formation) + $0.08 \times 2$ (propionate formation) $+2.26 \times 2\left(P / \mathrm{NO}_{3}{ }^{-}=2\right)$.

From the ATP yields, $Y_{\text {ATP }}$ values between $5^{\circ} 0$ and $12 \cdot 6$ were calculated (Table 1 ). Stouthamer \& Bettenhaussen (1973) calculated theoretical curves relating $Y_{\text {ATP }}$ with the specific growth rate at various values of the maintenance coefficient. In our experiments the specific growth rates varied between 0.06 and $0.12 \mathrm{~h}^{-1}$. Assuming a maintenance coefficient for $P$. pentosaceum of $3 \mathrm{mmol} \mathrm{ATP} / \mathrm{g}$ dry wt/h (Stouthamer \& Bettenhaussen, 1973), $Y_{\text {ATP }}$ values between 12 and 16 were expected in our experiments. The lower values we obtained might have been caused by the high nitrite concentrations in the medium. This suggestion is 
consistent with the results of Hadjipetrou \& Stouthamer (1965) who found decreasing $Y_{\text {ATP }}$ values in $A$. aerogenes growing in the presence of increasing concentrations of nitrite. Lower $Y_{\mathrm{ATP}}$ values were also observed during accumulation of nitrite by Clostridium perfringens (Ishimoto et al. 1974). With $P$. pentosaceum grown in the presence of nitrate, too, a decrease in $Y_{\mathrm{ATP}}$ at increasing nitrite production was observed (Table I). Furthermore, bacteria grown anaerobically with or without nitrate did not grow when inoculated into a medium containing nitrite $(9 \mathrm{mM})$ but no nitrate. Thus the decrease in $Y_{\text {ATP }}$ found during increasing nitrite production from nitrate might be due to uncoupling of growth and energy production. When only small amounts of nitrite were accumulated the expected values for $Y_{\text {ATP }}$ were obtained for the various substrates, and we therefore conclude that the results support the basic assumptions made on the efficiency of oxidative phosphorylation for electron transport to nitrate.

\section{REFERENCES}

Anaerobe Laboratory Manuai (1972), p. I13. Edited by L. V. Holdeman and W. E. C. Moore. Blacksburg, Virginia, U.S.A.: Virginia Polytechnic Institute and State University.

Bergey's Manual of Determinative Bactfriology, 7 th edn (1957), p. 576. Edited by R. S. Breed, E. G. D. Murray and N. R. Smith. Baltimore, Maryland, U.S.A.: The Williams and Wilkins Co.

Chatx, P. \& Fromageot, C. (1942). Les cytochromes de Propionibacterium pentosaceum. Bulletin Social Chimique et Biologique 24, II 25-1127.

CHIBA, S. \& Isimoto, M. (1973). Ferredoxin-linked nitrate reductase from Clostridium perfringens. Journal of Biochemistry 73, 1315-1318.

Cox, G. B., Newton, N. A., Gibson, F., Snoswell, A. M. \& Hamilton, J. A. (1970). The function of ubiquinone in Escherichia coli. Biochemical Journal 117, $551-562$.

DeEB, S. S. \& HAGer, L. P. (I964). Crystalline eytochrome $b_{1}$ from Escherichia coli. Journal of Biological Chemistry 239, 1024-I03I.

Delwiche, E. A. \& Carson, S. F. (1953). A citric acid cycle in Propionibacterium pentosaceum. Journal of Bacteriology 65, 318-32I.

Forrest, W. W. \& WALKER, D. J. (1971). The generation and utilization of energy during growth. In Advances in Microbial Physiology, vol. 5, pp. $213^{-274}$. Edited by A. H. Rose and J. F. Wilkinson. New York and London: Academic Press.

Gahwehn, K. \& Bergmeyer, H. U. (1970). In Methoden der Enzymatischen Analyse, vol. 2, pp. I450-I 453. Edited by H. U. Bergmeyer. Weinheim, Germany: Verlag Chemie.

Hadilpetrou, L. P. \& Stouthamer, A. H. (1965). Energy production during nitrate respiration by Aerobacter aerogenes. Journal of General Microbiology 38, 29-34.

Hatchikian, E. C. \& Le Gall, J. (1972). Evidence for the presence of a $b$-type cytochrome in the sulfatereducing bacterium Desulfovibrio gigas and its role in the reduction of fumarate by molecular hydrogen. Biochimica et biophysica acta 267, 479-484.

Hоновsт, H. J. (1970). In Methoden der Enzymatischen Analyse, vol. 2, pp. 1425-1429. Edited by H. U. Bergmeyer. Weinheim, Germany: Verlag Chemie.

INDERLIED, C. B. \& DelwiChe, E. A. (I973). Nitrate reduction and the growth of Veillonella alcalescens. Journal of Bacteriology 114, I 206-I 212.

Ishimoto, M., UMEYAMA, M. \& ChiBA, S. (I974). Alteration of fermentation products from butyrate to acetate by nitrate reduction in Clostridium perfringens. Zeitschrift fïr allgemeine Mikrobiologie 14, I I 5-I 2 I.

JACOBS, N. J. \& WoliN, M. J. (I963). Electron-transport system of Vibro succinogenes. I. Enzymes and cytochromes of the electron-transport system. Biochimica et biophysica acta 69, I8-28.

KAPRÁLEK, F. (1972). The physiological role of tetrathionate respiration in growing Citrobacter. Journal of General Microbiology 71, I33-139.

LipmanN, F. \& Tuttle, L. C. (1945). A specific micromethod for the determination of acyl-phosphates. Journal of Biological Chemistry 159, $2 \mathrm{I}-28$.

Lowry, O. H., Rosebrough, N. J., Farr, A. L. \& Randall, R. J. (195I). Protein measurement with the Folin phenol reagent. Journal of Biological Chemistry 193, 265-275.

PAYNE, W. J. (1973). Reduction of nitrogenous oxides by microorganisms. Bacteriological Reviews 37, 409-452. 
PICHINoty, F. (1973). La réduction bactérienne des composés oxygénés minéraux de l'azote. Bulletin de l'Institut Pasteur 71, 317-395.

van 'T Riet, J., Stouthamer, A. H. \& Planta, J. (1968). Regulation of nitrate assimilation and nitra te respiration in Aerobacter aerogenes. Journal of Bacteriology 96, I455-I464.

Rizza, V., Sinclair, P. R., White, D. C. \& Cuorant, P. R. (1968). Electron transport system of the protoheme-requiring anaerobe Bacteroides melaninogenicus. Journal of Bacteriology 96, 665-67r.

Rose, I. A., Grunberg-Manago, M., Korey, S. R. \& OchoA, S. (1954). Enzymatic phosphorylation of acetate. Journal of Biological Chemistry 211, 737-756.

SoNE, N. (1972). The redox reactions in propionic acid fermentation. I. Occurrence and nature of an electron transfer system in Propionibacterium arabinosum. Journal of Biochemistry 71, 931-940.

Stouthamer, A. H. (1973). A theoretical study on the amount of ATP required for synthesis of microbial cell material. Antonie van Leeuwenhoek 39, 545-565.

Stouthamer, A. H. \& BetTenhaussen, C. (1972). Influence of hydrogen acceptors on growth and energy production of Proteus mirabilis. Antonie van Leeuwenhoek 38, 8I-90.

Stouthamer, A. H. \& Bettenhaussen, C. (1973). Utilization of energy for growth and maintenance in continuous and batch cultures of microorganisms; A reevaluation of the method for the determination of ATP production by measuring molar growth yields. Biochimica et biophysica acta 3or, 53-70.

DE VRIES, W., Kapteyn, W. M. C., van Der BeEk, E. G. \& Stouthamer, A. H. (1970). Molar growth yields and fermentation balances of Lactobacillus case $\mathrm{L}_{3}$ in batch cultures and in continuous cultures. Journal of General Microbiology 63, 333-345.

De VRIES, W. \& Stouthamer, A. H. (1968). Fermentation of glucose, lactose, galactose, mannitol and xylose by bifidobacteria. Journal of Bacteriology 96, 472-478.

DE VRIEs, W., van WiJCK-KapteYN, W. M. C. \& Oosterhuis, S. K. H. (1974). The presence and function of cytochromes in Selenomonas ruminantium, Anaerovibrio lipolytica and Veillonella alcalescens. Journal of General Microbiology 81, 69-78.

DE VRIes, W., VAN WiJCK-KAPTEYN, W. M. C. \& StouthameR, A. H. (1972). Influence of oxygen on growth, cytochrome synthesis and fermentation pattern in propionic acid bacteria. Journal of General Microbiology 7r, 5I 5-524.

de Vries, W., van Wijck-Kapteyn, W. M. C. \& Stouthamer, A. H. (1973). Generation of ATP during cytochrome-linked anaerobic electron transport in propionic acid bacteria. Journal of General Microbiology $76,3 \mathrm{I}-4 \mathrm{I}$.

White, D. C., Bryant, M. P. \& Caldwell, D. R. (1962). Cytochrome-linked fermentation in Bacteroides ruminicola. Journal of Bacteriology 84, 822-828. 